\title{
Role of tour guides on tourist satisfaction level in guided tours and impact on re-visiting Intention: a research in Istanbul
}

DOI 10.1515/ejthr-2016-0005

received October 20, 2014; accepted February 22, 2015

\begin{abstract}
Traveller's wishes, needs and expectations keep changing constantly as destinations vie with each other to increase their share from the international tourism pie. Destinations need to offer qualified service and renew themselves continuously. In this context, tour guides as key representatives of destinations play a significant role on tourist satisfaction and re-visit intention. This research aims to ascertain the role played by tour guides on the satisfaction level of tourists participating in guided tours in Istanbul. Another aim of this research is to determine the impact level of tour guides on the possible re-visit intention of tourists to the same destination. Based on $530 \mathrm{com}$ pleted surveys from international tourists, the findings revealed a significant relationship between tourist satisfaction, re-visiting intention and tour guiding service. Following the evaluation of the findings, recommendations were developed for the tourism industry.
\end{abstract}

Keywords: Tour guide, Customer satisfaction, Customer loyalty, Re-visit intention, Istanbul.

\section{Introduction}

Tourism is accepted as one of the world's largest service industries. With the de-regulation of the airline industry,

\footnotetext{
*Corresponding author: Mehmet Yavuz Çetinkaya, Izmir Katip Celebi University, Faculty of Tourism, Department of Tourism Guidance, Balatçık Campus, Balatcik Yerleskesi, Cigli 35620, Cigli-Izmir, Turkey, Phone: 0090-554 8217385, E-mail: myavuzcetinkaya@gmail. com

Zafer Öter, Izmir Katip Celebi University, Faculty of Tourism, Department of Tourism Guidance, Balatçık Campus, Cigli-Izmir, Turkey
}

coupled with technological advancements, the emergence of e-commerce and demographic changes, it will continue to generate GDP and jobs across the world economy (Hui, Wan \& Ho, 2007). An ever-increasing number of destinations worldwide have opened up to, and invested in tourism, turning the tourism industry into a key driver of socio-economic progress through export revenues, the creation of jobs and enterprises and infrastructure development. Over the past six decades, tourism has experienced continued expansion and diversification, becoming one of the largest and fastest-growing economic sectors in the world (UNWTO, 2014).

According to the United Nations World Tourism Organization's (UNWTO) long-term forecast 'Tourism Towards 2030' in spite of the occasional shocks, there has been a virtually uninterrupted growth in the number of international tourist arrivals from 25 million in 1950 to 278 million in 1995, and 1087 million in 2013. In addition to this, international tourist arrivals worldwide are expected to increase by $3.3 \%$ a year from 2010 to 2030 to reach 1.8 billion by 2030. On the other hand, international tourism receipts in destinations in 2013 grew 5\% in real terms (taking into account exchange rate fluctuations and inflation) around the world and reached $\$ 1159$ billion.

Turkey has become one of the main tourist destinations in the Mediterranean rim, primarily because of its natural attractions, historical and cultural heritage and competitive prices, occupying the sixth place in the world's top tourism destinations in terms of hosting international tourists (34,910,098 million), and had a tourism receipt of $\$ 32,308.098$ billion (Yüksel, 2001; Ministry of Culture and Tourism, 2014). One of the most popular tourism destinations in Turkey, Istanbul, is a world centre of great value in the past as well as in the present, embracing Asia, on the one hand, and Europe, on the other hand, with its historical peninsula, numerous scenic and historical beauties. It is a magnificently unique city that hosted 10,474,867 million international tourists in 2013 (Go Turkey, 2014; Istanbul Directorate of Culture and Tourism, 2014). 
The increased leisure time as well as economic welfare level has led people to travel wide and participate in tourism activities worldwide. As a result of the increase of the international tourism activities in recent years, tourism receipts in several countries has increased significantly and destinations are finding themselves in a harsh competitive atmosphere (Şahin, 2012). The competitiveness of the market place and the increased expectations of customers have made tourism enterprises recognise the importance of customer service quality for future repeat and referral business (Bowie \& Chang,2005). However, little or no attention has been paid to the role of tourism industry employees, particularly those in tour guiding business, in the success of quality management programmes (Sharpley \& Forster, 2003). In this context, tour guides who are regarded as one of the representatives of countries and destinations and one of the most important front-line staff in the tourism industry play a significant role on tourist satisfaction and re-visit intention as the success of the service quality in the tourism industry very much depends on the performance of tour guides (Huang, Hsu \& Chan, 2010; Zhang \& Chow, 2004).

The objective of this study is to investigate the role played by tour guides on the satisfaction level of tourists participating in guided tours in Istanbul. Another purpose of this research is to determine the impact level of tour guides on the possible re-visit intention of tourists to the same destination.

\section{Literature review}

\subsection{Tour guiding: conceptual background}

Historically, guiding can be considered as one of the oldest human activities. Humans have roamed the earth since time immemorial, and the first historical accounts refer to people who lead the way: 'pathfinders', 'bear leaders', 'proxemos' and 'cicerones' were all antecedents of today's tour guides (Powell, 1993). The existence of guides started even two and a half millennia ago, but along with the beginning of modern mass tourism, they have become an important part of the travel industry. Today, without the service of tour guides, both tour managers and tour leaders (who accompany the group during the travel) and tour guides (who welcome the group at the destination), organised tourism is highly difficult (Rabotic, 2008).

There are many definitions of tour guides, provided by various organisations. The World Federation of Tourist
Guide Associations (WFTGA) defines a tour guide as a person who guides visitors in the language of their choice and interprets the cultural and natural heritage of an area, and who normally possesses an area-specific qualification usually issued and/or recognised by the appropriate authority (WFTGA, 2014). Another definition given by the Federation of Turkish Tourist Guides Associations (TUREB) is that a tour guide is a person who will introduce the country in the best way to the local and foreign tourists, will help them during their tour, will give them the right information and who has the authority document issued by the Culture and the Tourism Ministry (TUREB, 2014).

Even though there are different definitions of tour guide, an internationally accepted definition given by the International Association of Tour Managers (IATM) and the European Federation of Tourist Guide Associations (EFTGA) is that the tour guide is a person who guides groups or individual visitors from abroad or from the home country around the monuments, sites and museums of a city or region; to interpret in an inspiring and entertaining manner, in the language of the visitor's choice, the cultural and natural heritage and environment (EFTGA, 2014). According to the International Association of Tour Managers (IATM), tour guides act as 'buffers' among tourists, the social environment, arranging transportation, interpreting, handling problems, insulating travellers from difficulties and making the environment safe for tourists because they act as 'intermediaries' between tourists and the 'unknown' environment (Zhang \& Chow, 2004).

A skillful guide is one of the most valuable assets a tourism company can have. In many ways, a guide is the 'facade' of a business or company. Many foreign visitors tend to view their tour guides as representatives of the region or country. Although the Oxford dictionary defines a guide simply as 'a person who shows others the way', researchers have found the role of a tour guide to be much broader (Köroğlu, 2009). The focus of early studies on tour guides was on the topic of the role of tour guides. According to Cohen (1985), two lines of the modern tour guide's origin were 'pathfinder' and 'mentor'. The two origin lines were derived from the leadership and the mediatory spheres of the tour guide's role. Cohen (1985) further distinguished four major components of a tour guide's role. These components are instrumental, social, interactional and communicative. First of all, the instrumental component of the tour guide's role is related with his or her own responsibility for the smooth accomplishment of the tour as an ongoing social enterprise. Second, the social component is concerned with his or her own responsibility for the cohesion and morale of the touring 
party. Third, the interactional component refers to his or her own function as a middleman between his or her own party and the local population, sites, institutions and touristic facilities. In the fourth place, the communicative component relates to the tour guide's role of communicating destination-related information to tourists (Cohen, 1985). Other researches described the tour guide's role as 'a mediator', 'a middleman', or'culture broker'. These functions suggest that a tour guide acts as a cultural interface between the visitors and the host population and plays a vital role in interpreting the host culture to visitors (Huang, et al., 2010).

According to Tosun and Temizkan (2004), tour guides shoulder big duties and responsibilities in the tourism industry. Not only does the work of a tour guide involve the transmission of information, but it also involves presenting it in an interesting and sincere manner (Ap \& Wong, 2001). In addition to this, tour guides play an extremely important and diagnostic role on tourists' remaining pleased with tour organisation and travel experience (Zengin \& Ylldırgan, 2004).

In the opinion of many tourism researchers such as Cohen (1985), Ap and Wong (2001), Dahles (2002), Cohen, Maurice \& Cohen (2002) and Yu, Weiler and Ham (2001), the tour guide is

- A leader capable of assuming responsibility.

- An information giver and fountain of knowledge.

- A mentor (the role of the mentor resembles the role of teacher, tutor, instructor or advisor).

- A mediator and cultural brokerage; several studies have suggested that tour guides play a direct role in mediating cultural exchange between visitors and host cultures.
- An educator to help tourists understand the places they visit.

- An educator to help tourists understand lots of topics such as politics, economy, society, culture, religion, general knowledge, education, health, etc.

- An ambassador extending hospitality and presents the destination in a way that makes visitors want to return.

- A host creating a comfortable environment for tourists and a person influencing the quality of service and the tourist experience, the length of stay and the resulting economic benefits for a local community.

According to Leclerc and Martin (2004), tour guides provide information and anecdotal stories about the sites visited, places photographed and people encountered. Moreover, they provide a text to the silent panorama passing outside the windows of tour buses and they are often regarded as culture interpreters or culture brokers being the go-between for the tourists and local hosts and their cultural and communication competence play a significant role for those local hosts receiving 'hordes of culture-hungry tourists' (Leclerc \& Martin, 2004). The roles of tour guides were separated into three main groups and sub-groups, as indicated in Table 1.

There are so many terms that were used by different researchers for tour guides such as 'local guide' or 'tour coordinator'. In spite of the fact that there are not so many researches about tour guides, the roles and functions of tour guides in more general studies of guided tours have been identified by some researchers. The different roles of tour guides as defined by researchers are listed in Table 2 .

Table 1: The Roles of Tour Guides

\begin{tabular}{|c|c|c|}
\hline $\begin{array}{l}\text { Tour Management } \\
\text { (focus on group) }\end{array}$ & $\begin{array}{l}\text { Geographical } \\
\text { (original guide) } \\
\text { Organiser } \\
\text { Manager }\end{array}$ & $\begin{array}{l}\text { Social } \\
\text { (animator) } \\
\text { Entertainer } \\
\text { Facilitator }\end{array}$ \\
\hline $\begin{array}{l}\text { Experience Management } \\
\text { (focus on individual) }\end{array}$ & $\begin{array}{l}\text { Interactional } \\
\text { (tour-leader) } \\
\text { Group leader } \\
\text { Cultural broker }\end{array}$ & $\begin{array}{l}\text { Communicative } \\
\text { (Professional guide) } \\
\text { Educator } \\
\text { Teacher }\end{array}$ \\
\hline $\begin{array}{l}\text { Resource Management } \\
\text { (focus on environment) }\end{array}$ & $\begin{array}{l}\text { Motivate } \\
\text { Motivator }\end{array}$ & $\begin{array}{l}\text { Environmental interpreter } \\
\text { (naturalist guide) } \\
\text { Ecologist } \\
\text { Environmentalist }\end{array}$ \\
\hline
\end{tabular}

Source: Khalifah, 2007. 
Table 2: Published Studies on Roles of Tour Guides

\begin{tabular}{|c|c|c|}
\hline Roles & Researchers & Year \\
\hline Actor & Holloway & 1981 \\
\hline Ambassador & Hooloway & 1981 \\
\hline \multirow{4}{*}{ Buffer } & Schmidt & 1979 \\
\hline & Pearce & 1982 \\
\hline & Fine and Speer & 1985 \\
\hline & Holloway & 1981 \\
\hline Caretaker & Fine and Speer & 1985 \\
\hline Catalyst & Holloway & 1981 \\
\hline \multirow{2}{*}{ Culture Broker } & Holloway & 1981 \\
\hline & Katz & 1985 \\
\hline \multirow{2}{*}{ Information-giver } & Holloway & 1981 \\
\hline & Hughes & 1991 \\
\hline \multirow{2}{*}{ Intermediary } & Schmidt & 1979 \\
\hline & Ryan and Dewar & 1995 \\
\hline \multirow{4}{*}{ Interpreter/Translator } & Almagador & 1985 \\
\hline & Holloway & 1981 \\
\hline & Katz & 1985 \\
\hline & Ryan and Dewar & 1995 \\
\hline \multirow{2}{*}{ Leader } & Cohen & 1985 \\
\hline & Geva and Goldman & 1991 \\
\hline \multirow{4}{*}{ Mediator } & Schmidt & 1979 \\
\hline & Holloway & 1981 \\
\hline & Cohen & 1985 \\
\hline & Katz & 1985 \\
\hline Middleman & Van den Berghe & 1980 \\
\hline \multirow{3}{*}{ Organiser } & Hughes & 1991 \\
\hline & Pearce & 1982 \\
\hline & Schuchat & 1983 \\
\hline \multirow{2}{*}{ Salesperson } & Fine and Speer & 1985 \\
\hline & Gronroos & 1978 \\
\hline Shaman & Schmidt & 1979 \\
\hline \multirow{4}{*}{ Teacher } & Holloway & 1981 \\
\hline & Pearce & 1982 \\
\hline & Fine and Speer & 1985 \\
\hline & Manchini & 2001 \\
\hline
\end{tabular}

Source: Zhang and Chow, 2004.

\subsection{Tourist satisfaction and re-visiting concepts in tourism industry}

In today's world, all industries have been affected seriously by rapid change and competition. Having close relations with the customers for the business enterprises, which want to stay in the market and attempt to increase their market share by contributing highly to its own continuous improvement, has become compulsory due to great competition existing among the business enterprises in the industries (Bulut, 2011). Satisfying and retaining current and past customers is regarded as one of the most crucial objectives of the service providers. Customer satisfaction is a complex phenomenon in the study of consumer behaviour as customers are heterogeneous and they come with different needs and targets (Leguma, 2013). In this context, regardless of the industry, business enterprises, which have become conscious of this necessity, have been trying hard to increase the satisfaction level acquired from the offered goods and services and make up the portfolio of more loyal customer by having close communication with their customers (Bulut, 2011).

The international tourist market has shifted from a seller's market to a buyer's market. As a result of this change, the customers have a tendency for demanding cheaper holidays and have an increased requirement for high standards of product design. The competitiveness of the marketplace and the increased expectations of customers have made service providers recognise the importance of customer service for future repeat and referral business (Bowie \& Chang, 2005). In the tourism industry, there are many sectors such as accommodation, food and beverage and travel. Each individual attempt tries to measure customer satisfaction in accordance with their quality programmes. The importance of the customer satisfaction measurement has increased with quality, which is becoming more important in an increasing competition environment (Öztürk, 2004). In this regard, high levels of customer satisfaction have the following impacts: increasing the number of repeat visitations, influencing word of mouth recommendations and reducing customer complaints which are likely to undermine the organisation's reputation (Okello \& Grasty, 2009).

Satisfaction is a judgement on a product or service or service feature, or on the product or service as a whole. It is also claimed that satisfaction is a desirable end state of consumption; it is a pleasurable experience (Oliver, 1997). Moreover, satisfaction is defined as a psychological concept involving the feeling of well-being or pleasure, which results from a customer obtaining what one hopes or expects from a product or a service (Pizam \& 
Ellis, 1999). In the context of the tourism industry, tourist satisfaction is defined as the outcome of the comparison between expectations and experiences of the tourists (Truong \& Foster, 2006). Satisfaction is primarily referred to as a function of pre-travel expectations and post-travel experiences. On the condition that experiences compared to expectations result in feelings of gratification, the tourists will be satisfied and leave that destination with their good memory (Cam, 2011).

There are many factors playing a role on the satisfaction level of tourists making a visit to a certain destination in the tourism industry. These factors are the quality of transportation, accommodation and food \& beverage services, entertainment facilities, local people, behaviours and attitudes of tradesmen and price policies (Kozak, 2003). In addition to this, customer satisfaction with tourism products and services demands special attention because of the nature of the tourism products. In this context, Bowen and Clarke (2002) provide a useful analysis of the nature of the tourism products, stating that they have such distinctive characteristics as intangibility, inseparability, heterogeneity and perishability in nature (Leguma, 2013). Furthermore Jones and Sasser (1995) state that the relationship between satisfaction and loyalty is by no means linear. There is no alternative for unsatisfied customers, but to remain loyal in non-competitive marketplaces. However, in tourism industry, which is regarded as one of the highly competitive industries, satisfied customers have more alternatives and customer retention rates can be low. Since the tourism industry is a mature competitive market, it is more difficult to differentiate the tourism product significantly, but the key to differentiation may be service quality (Bowie \& Chang, 2005).

Tourism is one of the largest service industries in the world. On the condition that tourism is planned well, it can generate benefits at the destination by increasing tourist receipts, government revenue and employment. For more successful tourism development, it is crucial to attract tourists and to recommend the destination for others to visit (Chen \& Tsai, 2007). Recently, tourism marketing researches have focused mainly on competitiveness, attractiveness, tourist loyalty to a destination, tourist satisfaction and perceived service quality, and destination image (Buhalis, 2000; Beerli \& Martin, 2004; Yoon \& Uysal, 2005). Although there has been a little attention of repeat visitation, studies carried out recently investigated the role of re-visit in creating a more dynamic tourism sector and a more distinguished tourist experience (Oppermann, 1999; Kozak, 2001; Jang \& Feng, 2007; Hui et al., 2007). Repeat purchase has been accepted as one of the most important subjects in contemporary marketing. In many researches, benefits of repeat purchase are often noted as (a) attracting previous customers is more cost-effective than gaining new ones; (b) $5 \%$ increase in customer retention could increase profit by $25-85 \%$, and (c) customer retention tends to yield positive word-of-mouth referral (Jang \& Feng, 2007). Shoemaker and Lewis (1999) also add that repeat purchase is accepted as one of the most significant themes by its beneficial rewards such as creating positive word-of-mouth, achieving better cost-effective by repeat visitors and increasing economic profits.

In the tourism industry, repeat visits have also been accepted as an important phenomenon at the level of economy as a whole and for the individual attraction. Indeed, many travel destinations rely heavily on repeat visitors (Darnell \& Johnson, 2001). One of the earliest inquiries into the repeat visitation phenomenon was Gitelson and Crompton's (1984) study into the repeat vacation market and its marketing implications. They reported, 'Many attractions and destination areas such as beaches or resorts must rely heavily on repeat visitation'. In addition, they also mentioned five reasons why people undertake repeat visits: risk reduction/content with particular destination, risk reduction/find same kind of people, emotional attachments to a place, further exploration of destination, show destination to other people (Opperman, 2000).

In spite of the increased number of studies which have been carried out so far only very recently, a number of studies have been forwarded on the importance of repeat visitors to the same destination (Pereda, 2002). As there is an intense competition in tourism industry, different strategies have been developed in the tourism market share. Research showed that it would be extremely convenient for any given destination to develop customer retention and collect information about regular customers (Gitelson \& Crompton, 1984).

\subsection{Tourist satisfaction in guided tours and tour guiding service}

A guided tour is a special tourism product that is composed of many components organised and offered together by a tour operator (Bowie \& Chang, 2005). The components of a guided tour include pre-arrival services, accommodation, restaurants, transportation services and the tour guide/tour leader (Xu \& Chan, 2010). Tourists are accompanied by a tour leader or a tour guide during the on-tour process contrary to the independent travel, which is performed by the traveller himself/herself (Wang, Hsieh \& Huan, 2000). According to Enoch (1996), a guided tour 
is a rational and effective way of organising a holiday as it provides an opportunity to make visit to the many attractions in a short time period. Moreover, it is accepted as a less expensive way of travelling as the costs of transportation services are shared among the participants of the tour, which differ it from independent travel (Leguma, 2013).

Customer satisfaction in the tourism industry has become a complicated and interesting research topic to explore as the customers have distinctive characteristics such as heterogeneity and their perceptions and expectations tend to change over time (Leguma, 2013). In this regard, the evaluation of tourist satisfaction with guided tours is regarded as a complex process owing to the composition of guided tours. There are many tangible and intangible elements that compose the guided tour such as physical service features of the tour operator and intangible services provided by staff such as tour leaders or tour guides (Huang, et al., 2010). Customer satisfaction is composed of hard tangible and soft intangible service. It is a combination of, on the one hand, the customers' anticipation and perception of the vacation, their expectation prior to the tour, their attitudes and behaviour (past travel experience) and their perceptions of equity and unforeseeable events during service encounters (Bowie \& Chang, 2005). Furthermore, tourists have a chance to interact with different sectors such as transportation, accommodation, restaurants and attractions. This phenomenon creates a challenge in determining tourist satisfaction with guided tours as there is a hardship to remember the performance of every component for the tourists and compare it with their expectations (Leguma, 2013). Bowen and Clarke (2002) also add that maintaining the same levels of customer satisfaction in an environment involving many service encounters is complicated. In spite of the complexity of determining tourist satisfaction with guided tours, Wang et al., (2007) report that the success of guided tour operators can be affected by their skill to collect information about customer satisfaction and the use of this information to improve service delivery (Öter, 2010).

There are a number of factors playing a significant role in the determination of customer satisfaction in the tourism industry such as customers' expectations, previous experience and customer behaviour during the on-tour process, the perception of equity and unforeseeable events. These factors (Figure 1) are classified into two different groups, the first of which is internal factors constituting the customers' expectations, previous experience and customers' behaviour during the tour and the perception of equity and in the second group, which is titled as external factors composing of the factors such as unforeseeable events together with source of stress for tourists. The customer satisfaction is affected in three different stages of the tour by these factors (pre-tour, on-tour and post-tour) (Bowie \& Chang, 2005).

In the first stage (pre-tour), customer satisfaction is affected by customers' expectations and previous experience. During the second stage (on-tour process), customers' expectations, previous experience, visitors' behaviour, the perception of equity, unforeseeable events and customers' stress tend to affect the customer satisfaction. In the final stage (post-tour), customer satisfaction is mostly shaped by customers' experience (Leguma, 2013). In addition to this, these factors together with the tourism product and service characteristics are likely to result in customer satisfaction, partial satisfaction or customer dissatisfaction with tour experience (Swarbrooke \& Horner, 1999).

Tour guides occupy a very special position in the system. In terms of organisation, they are an essential part of the supply-side components. They can work for all of the supply-side stakeholders, within all of the sectors of the tourism industry. No matter who they are working for, tour guides are generally regarded as service providers for visitors (Pond, 1993). In addition to this, tour guides may be the most maligned people in the world of travel. They are blamed for the problems of travel, such as bad weather and traffic jams. They are expected to solve all the problems of the tourist - within or outside of their control (Prakash, Chowdhary \& Sunayana, 2011). Therefore Ang (1990) points out that tour guides are 'buffers' between the tourists and site visited.

Tour guides are one of the key front-line players in the tourism industry. Through their knowledge and interpretation of a destination's attractions and culture, and their communication and service skills, they have the ability to transform the tourists' visit from a tour into an experience (Ap \& Wong, 2001). Therefore, the success of the service

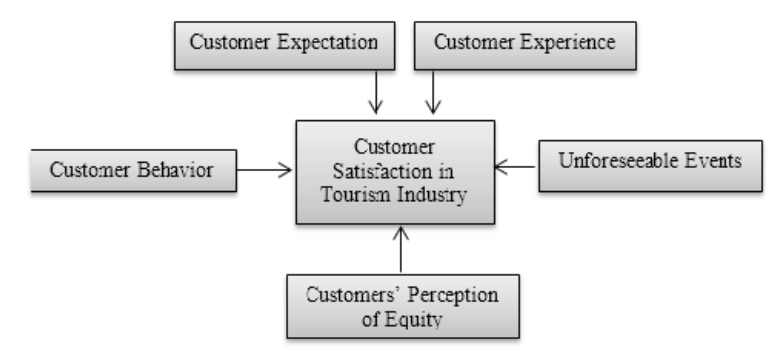

Figure 1: Factors Affecting Customer Satisfaction with Tourism Products and Services Source: Yüksel \& Yüksel, 2001; Bowie \& Chang, 2005 
quality in the tourism industry very much depends on the performance of tour guides (Köroğlu, 2009).

\section{Research methodology}

\subsection{Questionnaire design}

The questionnaire form was divided into three sections. The first part consisted of respondents' socio-demographic characteristics and preliminary questions were posed to respondents such as whether they had travelled to Istanbul before or not, if they travelled, how many times, what are the possible reasons of their preference for Istanbul as a destination, length of their stay in Istanbul, whether they participated in a guided tour before in Istanbul or not, reasons they have when participating in guided tours and how many times they attend guided tours annually. In the second part of the questionnaire, by using a 5-point Likert scale, ranging from 'highly dissatisfied (1)' to 'highly satisfied (5)'; from 'very unlikely (1)' to 'very likely (5)' and from 'very unimportant (1)' to 'very important (5)', respondents were asked questions to rate their satisfaction level they perceived from the service of travel agency that organised the tour, tour guide conducted the tour and to stress the possibility level of their making re-visit to Istanbul, recommendation of Istanbul as a destination to relatives and friends and impact level of tour guide in their possible decision of making re-visit to Istanbul. The last chapter of the questionnaire investigated respondents' satisfaction level, which they perceived from tour guides in terms of characteristics such as 'knowledge', 'skill' and 'personality' by using a 5-point Likert scale, ranging from 'terrible (1)' to 'excellent (5)'. In this context, after collecting professional advice from academic staff, trainers, travelers and veteran tour guides by personal interviews and e-mail, in all, 43 relevant attributes were identified such as 9 attributes in terms of knowledge, 12 attributes in terms of skill, and 22 attributes in terms of personality.

The survey instrument was entirely anonymous, no names were required from the respondents and it was not necessary to identify individually the specific tour guide during the data-collection process or to do a rating of the specific tour guide. This was important to make certain that tour guide allowed data collection in situ; to ensure that the data collection was not perceived as a threat to the guide's professional qualifications; and to assure that the information collected was at the group level. Tour guides were reassured that their employers had no means of identifying them individually and perhaps subsequently questioning their professional qualifications. The questionnaire form was designed in English.

A pilot test was conducted among 40 international tourists participating in guided tours in Istanbul in September 2012 and every respondent was given an 'evil eye bead' representing Turkish culture as a souvenir to encourage them and increase response rates. Some necessary changes were made based on the results of the pilot test.

\subsection{Sampling}

A detailed literature review through books, journals, articles and thesis in Turkish and English languages about the concepts of tour guiding, customer satisfaction, customer loyalty and re-visit intention in tourism industry was conducted. Then the survey method was chosen in order to collect primary data. The survey method applied in this research was chosen as it provided certain advantages such as being applicable to people from all age groups, enabling to make practice on big groups and collect adequate information for the research purpose, express the collected data numerically, provide a fast access to the collected data and being economic (Yazıcıoğlu \& Erdoğan, 2004).

The sample consisted of a total of 600 collected surveys from international tourists mainly coming from countries whose native language is English such as United States of America (USA), Canada, Australia, England (UK) and other European countries whose citizens have a fluent level in English language.

\subsection{Data collection}

This research was carried out in Istanbul, whose scope accounts for the international tourists participating in guided tours. The main reason for choosing Istanbul as a research area is its high number of international tourist arrivals. The number of international tourist arrivals of Istanbul is 10,474,867 in 2013, which is indicated in Figure 2. There are some other reasons that are considered to have played a fundamental role in choosing Istanbul destination as a research area such as being the most developed and biggest city of Turkey, having some of the most majestic and splendid monuments of the world, a meeting point of different cultures, nations and religions since history and being the most important destination in terms 
of cultural tourism considering the fact that tour guides have an important impact on the overall satisfaction level of tourists in cultural tours.

The research was conducted in October and November 2013 in Istanbul with600 international tourists. In the scope of the research, tour guides who were randomly met at the main touristic sites of Istanbul such as Topkap1 Palace, Dolmabahçe Palace, Hagia Sophia and Sultan Ahmet Mosque etc., which are generally visited by both international and domestic tourists, and were asked to give the questionnaire form to their tourist groups. The data collection was done towards the end of the tourists' travel experiences to ensure that tourists could correctly answer questions dealing with the assessment of their travel experience. Since the subjects were on vacation and therefore did not wish to spend a great deal of time filling out the survey questionnaire, they were all approached briefly while still in the bus at the end of a travel day. The researchers boarded the tour bus, gave a brief introduction of the research and asked for participation. Out of 600 questionnaire forms, 70 questionnaire forms were excluded from the evaluation due to the missing data to the extent of $40 \%$. As a result of this, 530 questionnaire forms were evaluated so as to make the reliability test and the obtained result was calculated as Cronbach's Alpha $=0.989$. This rate indicates that the scale is highly reliable (Kayıs, 2010).

\subsection{Data analysis}

The collected questionnaire forms were forwarded to SPSS (Statistical Package Program for Social Sciences - Version
20) and all the analyses were implemented through this program. Descriptive analysis such as frequency, mean and standard deviation were conducted to examine visitors' demographic profiles. Cronbach's alpha was calculated to test the reliability of the importance of a tour guide's service quality attributes and the performance as perceived by the respondents. A factor was considered significant if its Cronbach's alpha was 0.50 or above (Hair et al., 1998).

\section{Research findings}

\subsection{The profile of respondents}

The socio-demographic characteristics of the tourists are profiled in Table 3. The majority of the respondents are females (50.9\%) followed by males (47.2\%). In terms of marital status, married (62.3\%) respondents are more than unmarried respondents (23.4\%). The majority of the respondents have a bachelor degree (47.2\%) followed by a master or doctoral degree (24.2\%). While $15.8 \%$ of the respondents have vocational education, $7.5 \%$ of the respondents have secondary education. The last group only accounted for primary education with a percentage of (1.6\%). The annual income of the respondents was classified into eight groups and the main group was $15.5 \%$ representing (30,001-45,000€). The following seven groups are $14.3 \%$ (€60,001-75,000), 14.3\% (€90,000 and more ), $10.6 \%$ (€75,000-90,000), 10.2\% (€45,001-60,000), 8.3\% (€7500 and less), 6.8\% (€15,001-30,000) and 4.9\% (€750115000). The main age group was 60 and older, representing

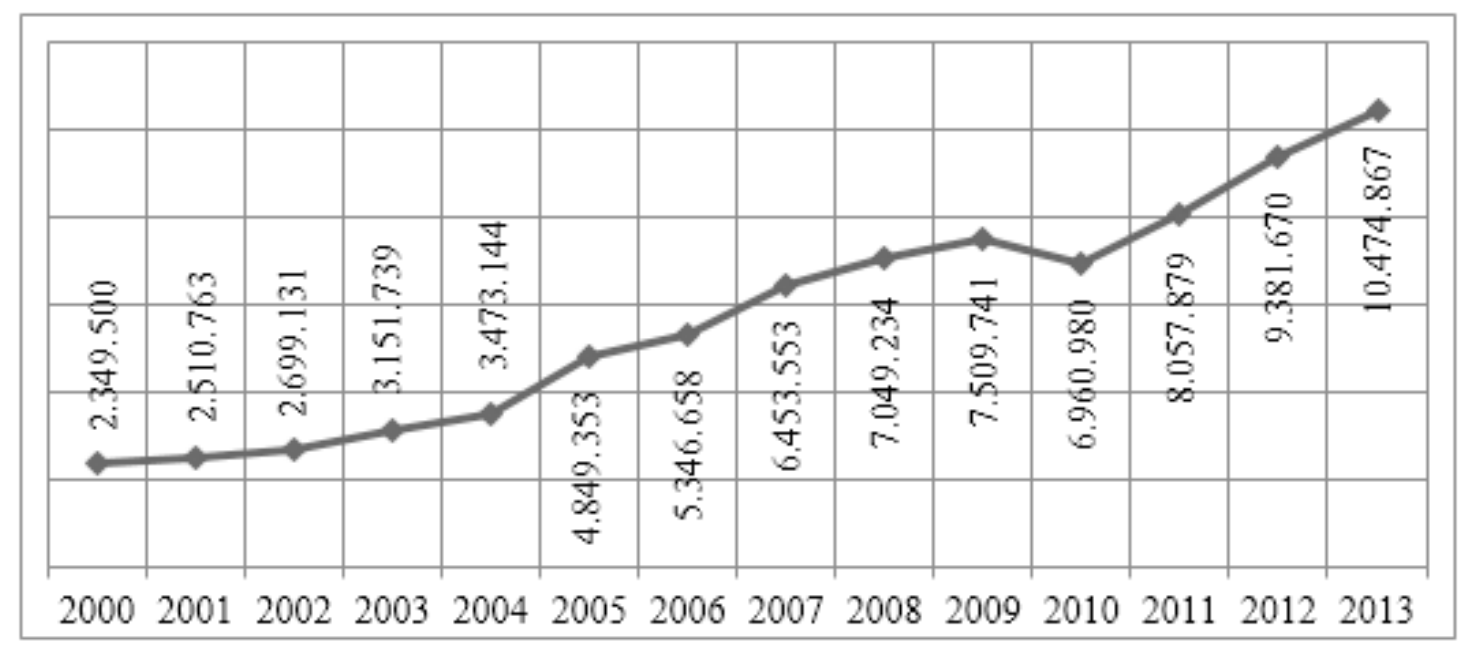

Figure 2: The Number of International Tourist Arrivals Istanbul (2000-2013) 
$39.2 \%$. The next six groups were 40-49 (18.9\%), 30-39 (15.8\%), 50-59 (13.6\%), 20-29 (7.9\%), 16-19 (1.1\%) and 15 or less $(0.8 \%)$. Regarding the current position of the respondents, the main group was employee representing (40\%) followed by retired, representing (32.5\%), housewife man /carer, representing (5.3\%), student, representing (4.9\%), unemployed, representing (3.8\%) and others, representing $(10.9 \%)$. In brief, respondents are balanced in terms of gender. Other characteristics of respondents vary. They are generally married, with undergraduate/ graduate education level, mid to third age group member employees and retired travellers.

Table 4 indicates the country profile of respondents. The majority of the respondents are from USA (34.0\%), followed by UK (13.6\%), Australia (11.7\%) and Canada (10.9\%). Istanbul receives visitors from diverse parts of the world, but Anglo-Saxon visitor profile seems visibly overwhelming on other categories.

Regarding the respondents' frequency of attending guided tours annually, the majority of the respondents

Table 3: Socio-Demographic Profiles of Respondents

\begin{tabular}{|c|c|c|c|c|c|}
\hline \multicolumn{6}{|c|}{ Socio-Demographic Characteristics } \\
\hline Gender & $\mathrm{N}$ & $\%$ & Age Group & $\mathrm{N}$ & $\%$ \\
\hline Male & 250 & 47.2 & 15 or younger & 4 & 0.8 \\
\hline Female & 270 & 50.9 & $16-19$ & 6 & 1.1 \\
\hline Marital Status & $\mathrm{N}$ & $\%$ & $20-29$ & 42 & 7.9 \\
\hline Married & 330 & 62.3 & $30-39$ & 84 & 15.8 \\
\hline Single & 124 & 23.4 & $40-49$ & 100 & 18.9 \\
\hline Other & 58 & 10.9 & $50-59$ & 72 & 13.6 \\
\hline Educational Qualification & $\mathrm{N}$ & $\%$ & 60 or over & 208 & 39.2 \\
\hline Primary school & 8 & 1.6 & Current Position & $\mathrm{N}$ & $\%$ \\
\hline Secondary School & 40 & 7.5 & Employee & 212 & 40 \\
\hline Vocational Education & 84 & 15.8 & Housewife/Man or Carer & 28 & 5.3 \\
\hline Bachelor Degree & 250 & 47.2 & Retired & 172 & 32.5 \\
\hline Master or Doctoral Degree & 128 & 24.2 & Student & 26 & 4.9 \\
\hline Income Group (Euro) & $\mathrm{N}$ & $\%$ & Unemployed & 20 & 3.8 \\
\hline 7,500 or Less & 44 & 8.3 & Others & 58 & 10.9 \\
\hline $7,501-15000$ & 26 & 4.9 & & & \\
\hline $15,001-30,000$ & 36 & 6.8 & & & \\
\hline $30,001-45,000$ & 82 & 15.5 & & & \\
\hline $45,001-60,000$ & 54 & 10.2 & & & \\
\hline $60,001-75,000$ & 76 & 14.3 & & & \\
\hline $75,001-90,000$ & 56 & 10.6 & & & \\
\hline More than 90,000 & 76 & 14.3 & & & \\
\hline
\end{tabular}


$58.1 \%$ attend guided tours annually one or two times and the following three groups are $25.3 \%$ (3-5 times), $6.8 \%$ (6-10 times) and lastly $3.4 \%$ attend guided tours annually 11 and more times. In terms of respondents' number of visits to Istanbul, the main group was $74.7 \%$ (first time), and followed by $14.0 \%$ (second time), $6.0 \%$ (third time), $1.5 \%$ (fourth time) and lastly $0.8 \%$ (fifth and more). The majority of the respondents $(75.8 \%)$ stated that they did not attend any guided tour before in Istanbul while the rest of the respondents (16.2\%) had experience in guided tours in Istanbul. A quarter of visitors have been to Istanbul before, and most of visitors are familiar with touring experience and they seem to take guided tours during their first visit to Istanbul (Table 5).

When the results concerning the respondents' reasons for choosing Istanbul as a destination were examined, $59.9 \%$ of the respondents stated that they chose Istanbul to have a holiday. The remaining groups are as follows: visit a cultural destination (22.6\%), shopping (6.4\%), visit relatives and friends (2.5\%), attend cultural event $(2.5 \%)$, conference $(2.2 \%$,), business (1.1), sport events $(0.8 \%)$ and lastly $1.9 \%$ of the respondents chose Istanbul for other reasons. Holiday and cultural visits are the top motivators of visitors in Istanbul (Table 6).

In terms of the respondents' length of stay in Istanbul, the main group was 4 days with a percentage level of 18.5 $\%$. The following groups were listed as $16.9 \%$ (1 day or less), 13, and $6 \%$ (3 days), 12.5\% (5 days), 7.5\% (2 days), 6.8\% (7 days), 5.7\% (8 days), 3.8\% (6 days), 3.8\% (9 days),

Table 4: Country Profile of Respondents

\begin{tabular}{|c|c|c|c|c|c|}
\hline \multicolumn{6}{|c|}{ Country Profile of Respondents } \\
\hline Country & $N$ & $\%$ & Country & $N$ & $\%$ \\
\hline Australia & 62 & 11.7 & Iraq & 4 & 0.8 \\
\hline Belgium & 4 & 0.8 & Italy & 2 & 0.4 \\
\hline Brazil & 2 & 0.4 & Mexico & 4 & 0.8 \\
\hline Canada & 58 & 10.9 & Netherland & 12 & 2.3 \\
\hline Chili & 2 & 0.4 & Norway & 10 & 1.9 \\
\hline Denmark & 12 & 2.3 & Puerto Rico & 2 & 0.4 \\
\hline England & 72 & 13.6 & Russia & 8 & 1.5 \\
\hline Estonia & 2 & 0.4 & Scotland & 2 & 0.4 \\
\hline Finland & 6 & 1.1 & Sweden & 18 & 3.4 \\
\hline France & 8 & 1.5 & Switzerland & 2 & 0.4 \\
\hline Germany & 26 & 4.9 & USA & 180 & 34.0 \\
\hline Hungary & 2 & 0.4 & Missing & 30 & 5.7 \\
\hline
\end{tabular}

$3.8 \%$ (10 days and more). The majority of visitors stay less than a week in Istanbul and those who stay less than 3 days consist of nearly half of the visitors (Table 7).

Regarding the respondents' reasons for attending guided tours in Istanbul, the majority of the respondents attended guided tours in order to learn more about Istanbul's historical and cultural sites with a percentage of $29.8 \%$. Attending the guided tour to learn more about Turkey corresponded to $19.5 \%$. The following groups were $12.5 \%$ (lack of local language knowledge), 14.2\% (to get qualified information), $10.0 \%$ (to have an enjoyable time), 6.3\% (responsibility and organisation belong to travel agency), 5.7\% (not to be anxious to go around alone), and lastly, $2.1 \%$ of the respondents attended the guided tour for other reasons (Table 8).

\subsection{Respondents' satisfaction level on travel agency and tour guide}

Figure 3 indicates the satisfaction level that the respondents perceived from the travel agency that organised the tour. According to the results, the majority of the respondents were satisfied to the extent of $50.2 \%$ and this is followed by $34 \%$ (highly satisfied). The percentage of the highly dissatisfied and dissatisfied were realised as $4.6 \%$ and lastly $8.3 \%$ of the respondents stayed as neutral.

In terms of the satisfaction level that respondents perceived from the service of the tour guide, the majority of the respondents were satisfied with a percentage level of ( $40.4 \%$ ) and this rate is followed by $24.2 \%$ (highly satisfied). $6.8 \%$ of the respondents were dissatisfied and lastly $25.3 \%$ stayed neutral (Figure 4).

\subsection{Respondents' likelihood on re-visit intention and recommendation of Istanbul}

Concerning the respondents' likelihood on making a re-visit to Istanbul, on the one hand, the majority (64.6\%) of the respondents expressed that they would re-visit Istanbul; on the other hand only $6.8 \%$ of the respondents stated that their possibility of re-visiting Istanbul is unlikely or very unlikely. Lastly, $25.3 \%$ of the respondents stayed uncertain (Figure 5).

Regarding the respondents' likelihood of recommendation to relatives and friends, Figure 6 indicates that the majority of the respondents would recommend Istanbul as a destination to their relatives and friends with a percentage of $86.4 \%$ and only $3.1 \%$ of the respondents stated that their likelihood of recommendation is very unlikely or 
Table 5: Respondents' Frequency in Attending Guided Tours, Number of Visits, Tour Experience

\begin{tabular}{|c|c|c|c|c|c|}
\hline $\begin{array}{l}\text { How often do you attend } \\
\text { guided tours annually? }\end{array}$ & $\mathrm{N}$ & $\%$ & $\begin{array}{l}\text { How many times have you } \\
\text { ever been in Istanbul? }\end{array}$ & $\mathrm{N}$ & $\%$ \\
\hline $1-2$ times & 308 & 58.1 & $1 \mathrm{st}$ & 396 & 74.7 \\
\hline $3-5$ times & 134 & 25.3 & 2nd & 74 & 14.0 \\
\hline $6-10$ times & 36 & 6.8 & $3 r d$ & 32 & 6.0 \\
\hline More than 11 times & 18 & 3.4 & 4th & 8 & 1.5 \\
\hline $\begin{array}{l}\text { Have you ever joined a } \\
\text { guided tour in Istanbul before? }\end{array}$ & $\mathrm{N}$ & $\%$ & 5 th & 4 & 0.8 \\
\hline Yes & 86 & 16.2 & & & \\
\hline No & 402 & 75.8 & & & \\
\hline
\end{tabular}

Table 6: Respondents' Travelling Reasons to Istanbul

What is the primary purpose of your current trip?

\begin{tabular}{llllll}
\hline Purpose & $\mathrm{N}$ & $\%$ & & $\mathrm{~N}$ & $\%$ \\
Holiday & 430 & 59.9 & Conference & 16 & 2.2 \\
Visit Cultural Attraction & 162 & 22.6 & Sport Event & 6 & 0.8 \\
Attend Cultural Event & 18 & 2.5 & Shopping & 46 & 6.4 \\
Visit Relatives and Friends & 18 & 2.5 & Others & 14 & 1.9 \\
Business & 8 & 1.1 & Total & & 718 \\
\cline { 2 - 3 }
\end{tabular}

Table 7: Respondents' Stay Length in Istanbul

\begin{tabular}{llllll}
\multicolumn{7}{l}{ How many } & nights will you be staying in Istanbul? \\
\hline Day & N & $\%$ & Day & N & $\%$ \\
1 day & 90 & 16,9 & 6 days & 20 & 3,8 \\
2 days & 40 & 7,5 & 7 days & 36 & 6,8 \\
3 days & 72 & 13,6 & 8 days & 30 & 5,7 \\
4 days & 98 & 18,5 & 9 days & 20 & 3,8 \\
5 days & 66 & 12,5 & 10 days and more & 20 & 3,8 \\
\hline
\end{tabular}

To what extend are you satisfied with the tour you attended organised by the travel agency?

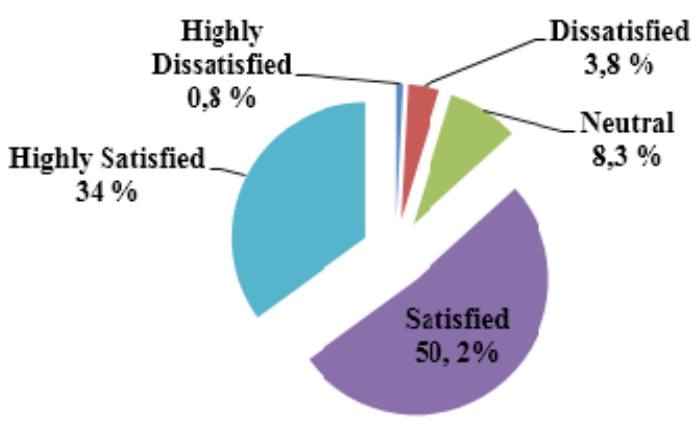

Figure 3: Respondents' Satisfaction Level on Travel Agency
Table 8: Respondents' Attending Reasons to Guided tour in Istanbul

Why did you prefer to join this guided tour in Istanbul?

\begin{tabular}{lll} 
Purpose & N & $\%$ \\
\hline Because I don't know local language & 170 & 12.5 \\
$\begin{array}{l}\text { In order to learn more about Istanbul's } \\
\text { historical and cultural sites }\end{array}$ & 406 & 29.8 \\
Not to be anxious to round out alone & 78 & 5.7 \\
Responsibility organization belongs to travel & 86 & 6.3 \\
agency & 266 & 19.5 \\
In order to learn more about Turkey & 194 & 14.2 \\
In order to get qualified information & 136 & 10.0 \\
In order to have an enjoyable time & 28 & 2.1 \\
Others & 1364 & 100 \\
Total & & \\
\hline
\end{tabular}

unlikely. Lastly, 7.9\% of the respondents stayed as uncertain (Figure 6).

\subsection{Impact of tour guides on respondents' possible decision of re-visit intention}

On examining the results related with the respondents' answers about the possible impact level of tour guides on respondent's possible decision re-visiting Istanbul, it is found that the majority of the respondents rated the impact level of tour guide as important (45.3\%) followed 
by respondents who stated the impact level of tour guides as very important (17.4\%). And $14.7 \%$ of the respondents rated this attribute as not important. Lastly, $18.9 \%$ of the respondents stayed as neutral (Figure 7).

\section{Conclusion and recommendation}

Considering tourism and tour guiding context in Turkey, tourism and related activities are of great significance in terms of providing revenue and economic growth. This being the case, satisfaction of tourist with guided tours in this very limited context holds its righteous place in

To what extend are you satisfied with the tour guide conducted the tour you attended?

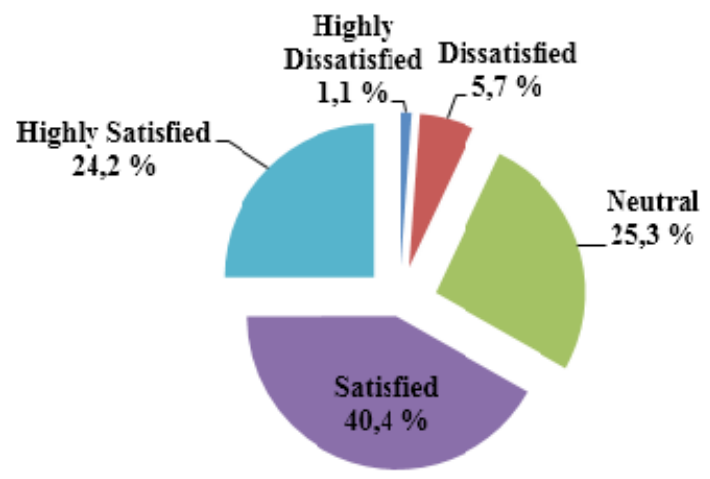

Figure 4: Respondents' Satisfaction Level on Tour Guide

How likely are you to come back to Istanbul again?

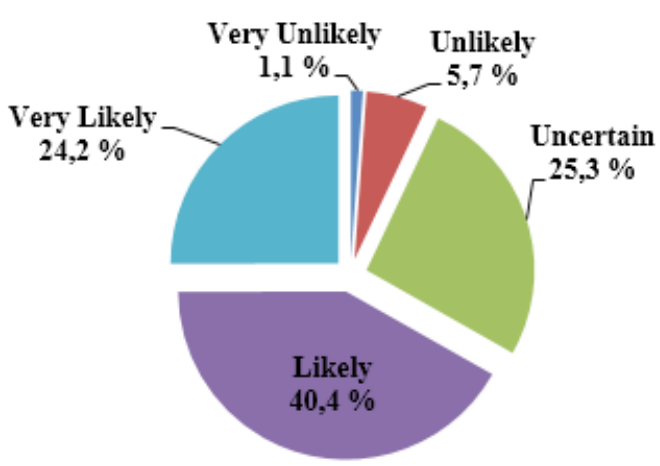

Figure 5: Respondents' Re-visit Intention to Istanbul Destination tourism. Another point to mention is that tour guiding, important as it is, has already caught the attention of researchers in the field of satisfaction, loyalty and re-visit intention. In this context, tour guides as one of the key front-line players in tourism industry transform the tourists' visit from a tour into an experience through their knowledge and interpretation of destination's attractions and culture, and their communication and service skills. Therefore, the success of the service quality in tourism industry very much depends on the performance of tour guides.

In the scope of the research, the satisfaction level of surveyed respondents, in which they perceived from the How likely are you to recommend your holiday in Istanbul to your relatives and friends?

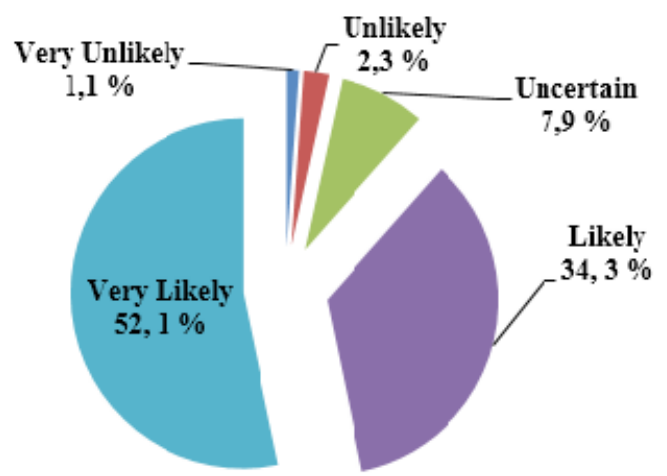

Figure 6: Respondents' Intention of Recommending Istanbul Destination

service of the travel agency that organised the guided tour What is the importance level of tour guide in your possible decision of re-visiting Istanbul?

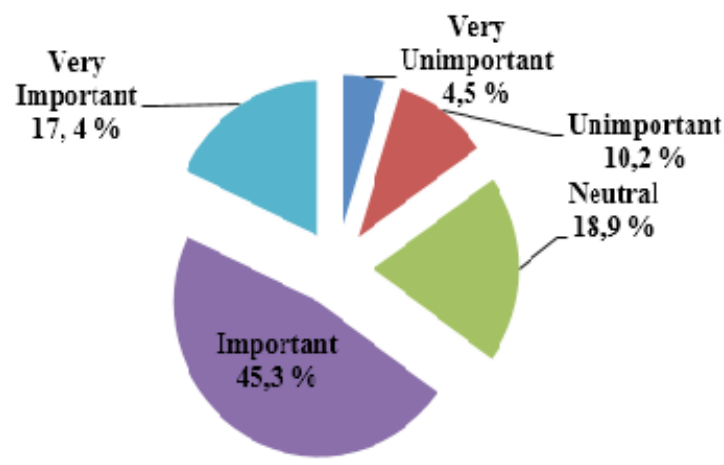

Figure 7: Tour Guides' Impact Level on Respondents' Revisit Intention 
was $50.2 \%$ (satisfied) followed by 34\% (highly satisfied). Therefore, it can be stated that the travel agencies operating in Istanbul have an important position in the tourism industry and they meet the needs and expectations of tourists visiting Istanbul at a high level. Another point which is clear from the research findings is the re-visit intention of respondents. In accordance with the research results, it can be said that the majority of the respondents $(64.6 \%)$ stated that they re-visit Istanbul . This rate can be viewed as the international tourists having holiday and participating in guided tours in Istanbul return to their countries with a high level of satisfaction. In this context, they are possible candidates to become loyal customers in future periods. Furthermore, the fact that the majority of the respondents would like to make a re-visit to Istanbul revealed that the travel agencies operating in the region and tour guides conducting tours in Istanbul comprehended the importance of customer satisfaction and customer loyalty.

In terms of the respondents' recommendation of Istanbul to relatives and friends, as a result of the applied analysis, it is found out that $84.4 \%$ of the respondents stated that they would recommend Istanbul to their relatives and friends. The obtained result is a sign that the respondents would make word of mouth marketing for Istanbul in their home countries and in this regard the number of the international tourist arrivals in Istanbul will increase in the following years.

Regarding the respondents' satisfaction level, which they perceived from the service of tour guide, the majority of the respondents (40.4\%) were satisfied followed by $24.2 \%$ of highly satisfied respondents. One of the characteristics of tour guides such as 'knowledge' played a significant role in obtaining this satisfaction level. In this context, it can be commented that the tour guides working in Istanbul have sufficiency in terms of knowledge and they should increase their level of performance in terms of characteristics such as skill and personality. In addition to this, there are some other reasons for the high level of performance of tour guides in terms of knowledge characteristic such as importance given to undergraduate education at the university level in the field of tour guiding in recent years in Turkey as well as their self-education efforts.

The high level of education quality in the field of tour guiding will make a significant contribution to their professional life. Owing to this reason, universities should try hard to increase the quality of tour guiding education. Education in the field of tour guiding, in Turkey, is superior to the tour guiding education in many countries. In spite of the structural disorder, the education of tour guiding is highly taken into consideration in Turkey in comparison to many countries. As well as providing information to candidates to become tour guides, they should focus on skills such as communication with tourists, and conducting a tour in a successful way.

Concerning the results of the research, which investigated the impact level of tour guides on the possible decision of respondents to re-visit to Istanbul, it is revealed that the majority of the respondents (45.3\%) regarded the tour guides' role important. As a result of the fact that the majority of the people would like to attend the guided tour in Istanbul, it can be stated that the performance of the tour guide plays a fundamental role in achieving customer satisfaction and customer loyalty. In other words, the performance of a tour guide can shape the expectation of tourists, related to the performance of other tour guides. In this context, tour guides should provide a service to meet the expectations of tourists by taking needs, wishes and cultural differences of tourists into consideration.

\section{References}

[1] Ang, E. (1990). Upgrading the Professionalism of Tourist Guides. Proceedings from the Travel Educators Forum, (pp.167-172). PATA Conference, Singapore. 11-14 July 1990.

[2] Ap, J. \& Wong, K.F. (2001). Case Study on Tour Guiding: Professionalism, Issues and Problems. Tourism Management. 22(1): 551-563.

[3] Beerli, A. \& Martin, J.D. (2004). Factors Influencing Destination Image. Annals of Tourism Research. 31(3): 657-681.

[4] Bowen, D. \& Clarke, J. (2002). Reflections on Tourist Satisfaction Research: Past, Present and Future. Journal of Vacation Marketing. 8(4):297-308.

[5] Bowie, D. \& Chang, J.C. (2005). Tourist Satisfaction: A view from a Mixed International Guided Package Tour. Journal of Vacation Marketing. 11(4):303-322.

[6] Buhalis, D. (2000). Marketing the Competitive destination of the Future. Tourism Management. 21(1):97-116.

[7] Bulut, Y. “Otellerde Müşteri Memnuniyeti ve Bir Uygulama (Samsun Örneği)”, Uluslararası Sosyal Araştırmalar Dergisi, Vol.: 4, No.:18, 2011, pp. 390-403.

[8] Cam, T.T.A. (2011). Explaining Tourist Satisfaction and Intention to Re-visit Nha Trang, Vietnam. (Unpublished Master's Thesis). Norway: The Norwegian College of Fishery Science University of Tromso Vietnam: Nha Trang University.

[9] Chen, C. \& Tsai, D. (2007). How Destination Image and Evaluative Factors Affect Behavioral Intentions. Tourism Management. 28(4):1115-1122.

[10] Cohen, E. (1985). The Tourist Guide: The Origins, Structure and Dynamics of a Role.Annals of Tourism Research. 2 (1): 5-29.

[11] Cohen, E.H., Maurice, I. \& Cohen, E. (2002). A New Paradigm in Guiding the Madrich as a Model. Annals of Tourism Research. 29(4): 919-932. 
[12] Dahles, H. (2002). The Politics of Tour Guiding: Image Management of Indonesia. Annals of Tourism Research. 29(3): 783-800.

[13] Darnell, A.C., \& Johnson, P.S. (2001). Repeat Visits to Attractions: A Preleminary Economic Analysis. Tourism Management. 22(2):119-126.

[14] Gitelson, R.J. \& Crompton, J.L. (1984). Insights into the Repeat Vacation Phenomenon. Annals of Tourism Research. 11(2):199-217.

[15] Enoch, Y. (1996). Contents of Tour Packages: A cross-cultural comparison. Annals of Tourism Research, 23(3), 599-616.

[16] Hair, J.F., Anderson, R.E., Tatham, R.L. \& Black, W.C. (1998). Multivariate Data Analysis. New Jersey: Prentice Hall Publication.

[17] Huang, S., Hsu, C.H.C. \& Chan, A. (2010). Tour Guide Performance and Tourist Satisfaction: A Study of the Package Tours in Shanghai. Journal of Hospitality and Tourism Research. 34(1): 3-33.

[18] Hui K. T., Wan, D. \& Ho A. (2007). Tourists' Satisfaction, Recommendation and Revisiting Singapore.Tourism Management. 28(4): 965-975.

[19] Jang, S. \& Feng, R. (2007). Temporal Destination Revisit Intention: The Effects of Novelty Seeking and Satisfaction. Tourism Management. 28(2):580-590.

[20] Jones, T.O. \& Sasser, W.E. (1995). Why Satisfied Customers Defect. Harward Business Review. 73(6):1-14.

[21] Kayıs, A. (2010). Güvenirlilik Analizi, Ed., Kalaycı, Ş. Uygulamalı Çok Değişkenli İstatistik Teknikleri. Ankara: Asil Yayın Dağıtım.

[22] Khalifah, Zainab. (2007). Tour Guides Performance in Malaysia: Application of the Importance Performance Analysis. Proceedings of the 2007 International Tourism Biennial (pp.697-705). Çanakkale 18 Mart University, Çanakkale, Turkey. 30 April-5 May 2007.

[23] Kozak, M. (2003). Measuring Tourist Satisfaction with Multiple Destination Attributes. Tourism Analysis. 7(3-4): 229-240.

[24] Kozak, M. (2001). Repeaters' Behaviour at Two Distinct Destinations. Annals of Tourism Research.28 (3): 784-807.

[25] Köroğlu, Ö. (2009). The Relationship of the Factors which Affect the Level of Job Satisfaction and Motivation with Performance: An Investigation on Tourist Guides. (Unpublished Ph.D. Thesis). Turkey: Balıkesir University, Graduate School of Social Sciences.

[26] Leclerc, D. \& Martin, J.N. (2004). Tour Guide Communication Competence: French, German and American Tourists' Perceptions. International Journal of Intercultural Relations, 28 (3-4): 181-200.

[27] Leguma, E.O. (2013). Visitor Satisfaction with Guided Package Tours in the Northern Tourist Circuit of Tanzania. (Unpublished Master's Thesis). New Zealand: Victoria University of Wellington.

[28] Okello, M.M., \& Grasty, K. (2009). The Role of Large Mammals and Protected Areas to Tourist Satisfaction in the Northern Circuit, Tanzania. Tourism Analysis. 14 (5):691-697.

[29] Oliver, R.L. (1997). Satisfaction: A Behavioral Perspective on the Consumer. New York: McGraw -Hill.

[30] Oppermann, M. (1999). Predicting Destinations Choice- A Discussion of Destination Loyalty. Journal of Vacation Marketing,5(1): 51-65.

[31] Oppermann, M. (2000). Tourism Destination Loyalty. Journal of Travel Research. 39(1):78-84.
[32] Öter, Z. (2010). Turist Rehberlerinin Pazarlama Bilgisi Toplama Davranışları. Journal of Travel and Hospitality Management. 7(1): 25-37.

[33] Öztürk, A.B. (2004). Factors Affecting Tourist Satisfaction in Kızkalesi Area. (Unpublished Master's Thesis). Turkey: Mersin University, Graduate School of Social Sciences.

[34] Pereda, M. H. (2002). Repeat Visitors of a Tourist Destination. Journal of Tourism Research. 36(1): 35-43.

[35] Pizam, A. \& Ellis, Taylor. (1999). Customer Satisfaction and Its Measurement in Hospitality Enterprises. International Journal of Contemporary Hospitality Management.11 (7): 326-339.

[36] Pond, L.K. (1993). The Professional Guide: Dynamics of Tour Guiding. New York: Van Nostrand Reinhold.

[37] Powell, L.F. (1993). The Tour Guide: A Historical Overview. The Professional Guide: Dynamics of Tour Guiding (pp.1-13). Editor Kathleen Lingle Pond. New York: Van Nostrand Reinhold.

[38] Prakash, M., Chowdhary, N. \& Sunayana (2011). Tour guiding: Interpreting the challenges. Turismos: An International Multidisciplinary Journal of Tourism. 6(1): 65-81.

[39] Rabotic, B. (2008). Tourist Guides as Cultural Heritage Interpreters: Belgrade Experience with Municipality-Sponsored Guided Walks for Local Residents. International Tourism Conference: Cultural and Event Tourism Issues \& Debates (pp. 213-233). Akdeniz University. Alanya, Turkey. 5-9 November 2008.

[40] Sharpley, R. \& Forster, G. (2003). The implications of Hotel Employee Attitudes for the Development of Quality Tourism: The Case of Cyprus. Tourism Management. 24(6): 687-697

[41] Shoemaker, S. \& Lewis, R.C. (1999). Customer Loyalty: The Future of Hospitality Marketing. The Journal of Hospitality Management,18(4):345-346.

[42] Şahin, S. (2012). Intercultural Communication Efficiencies of Tourist Guides: The Perceptions of German, English and Russian Tourists. (Unpublished Ph.D. Thesis). Turkey: Balıkesir University, Graduate School of Social Sciences.

[43] Swarbrooke, J. \& Horner, S. (1999). Consumer Behaviour in Tourism.Oxford: Butterworth Heinemann.

[44] Tosun, C. \& Temizkan, R. (2004). Türkiye'nin Dış Tanıtımın ve Ülke İmajında Turist Rehberlerinin Rolü. I. Balıkesir Ulusal Turizm Kongresi (pp.345-362). Balıkesir Üniversitesi Turizm Fakültesi. Balıkesir, Turkey. 15-17 Nisan 2004.

[45] Truong, T.H. \& Foster, D. (2006). Using HOLSAT to Evaluate Tourist Satisfaction at Destinations: The Case of Australian Holidaymakers in Vietnam. Tourism Management. 27 (1):842-855.

[46] Wang, K.C., Hsieh, A.T. \& Huan, T.C. (2000). Critical Service Features in Group Package Tour: An Exploratory Research. Tourism Management. 21(2):177-189.

[47] Xu, J.B. \& Chan, A. (2010). Service Experience and Package Tours. Asia Pacific Journal of Tourism Research. 15(2): 177-194.

[48] Yazıcıoğlu, Y \& Erdoğan, S. (2004). SPSS Uygulamalı Bilimsel Araştırma Yöntemleri. Ankara: Detay Yayıncılık

[49] Yoon, Y. \& Uysal, M. (2005). An Examination of the Effects of Motivation and Satisfaction on Destination Loyalty: A Structural Model. Tourism Management. 26(1):45-46.

[50] Yu, X., Weiler, B. \& Ham, S. (2001). Intercultural Communication and Meditation: A Framework for Analyzing the Intercultural Competence of Chinese Tour Guides. Journal of Vacation Marketing. 8(1):75-87. 
[51] Yüksel, A. (2001). Managing Customer Satisfaction and Retention: A Case of Tourist Destinations, Turkey. Journal of Vacation Marketing. 7 (2): 153-168.

[52] Yüksel, A. \& Yüksel, F. (2001). Measurement and Management Issues in Customer Satisfaction Research: Review, Critique and Research Agenda: Part One. Journal of Travel and Tourism Marketing. 10(4):47-80.

[53] Zengin, B. \& Yıldırgan, R. (2004). Seyahat Acentelerinin Turist Rehberlerinden Beklentilerine Yönelik Bir Araştırma. I. Balıkesir Ulusal Turizm Kongresi (pp.366-376). Balıkesir Üniversitesi Turizm Fakültesi. Balıkesir, Turkey. 15-17 Nisan 2004.

[54] Zhang, H.Q. \& Chow, I. (2004). Application of ImportancePerformance Model in Tour Guides' Performance: Evidence from Mainland Chinese Outbound Visitors in Hong Kong. Tourism Management. 25(1):81-91

[55] Internet References

[56] EFTGA (European Federation of Tourist Guide Associations). “ About FEG". Avaliable at http://www.feg-touristguides.com/ about-feg.html. (Accessed 15.04.2013).

[57] Go Turkey (Official Tourism Portal of Turkey). " General Information about Istanbul”. Avaliable at https://www. goturkey.com/tr/city/detail/istanbul. (Accessed 10.04.2013).

[58] Ministry of Culture and Tourism." International Tourist Arrivals”. Avaliable at http://sgb.kulturturizm.gov.tr/ Eklenti/29269,gelen-yabanci-ziyaretci-sayisi.pdf?0. (Accessed 10.04.2013).

[59] Ministry of Culture and Tourism Istanbul Directorate of Culture and Tourism. "Tourism Statistics of Istanbul”. Avaliable at http://www.istanbulkulturturizm.gov.tr/TR,71515/turizmistatistikleri.html. (Accessed 10.04.2013).

[60] TUREB (Association of Turkish Tourist Guides). "Who is a Tourist Guide?”. Available at http://www.tureb.org.tr/index. php?mod=sayfa_goster $\&$ sid $=13 \&$ sayfa $=$ Genel\%20Bilgiler (Accessed 10.04.2013).

[61] UNWTO (United Nations of World Tourism Organization). “Tourism Highlights, 2014 Edition" Available at: http://mkt. unwto.org/publication/unwto-tourism-highlights-2014-edition. (Accessed 25.09.2014).

[62] WFTGA (World Federation of Tourist Guide Association). "What is a tourist guide?". Available at:http://www.wftga.org/touristguiding/what-tourist-guide. (Accessed 10.04.2013).

Mehmet Yavuz Çetinkaya is research assistant in Izmir Katip University - Faculty of Tourism - Turkey. Furthermore, he is a Ph.D candidate in the Department of Tourism Management, Graduate School of Social Sciences in Izmir Katip Celebi University. Research interests focus on; tour guiding, cultural tourism; religious tourism, heritage interpretation and management and event tourism.

Zafer Öter is associate professor of tourism at Izmir Katip Celebi University-Faculty of Tourism in Turkey where he serves as vice-dean and department head. Previously, he served at Dokuz Eylul University - Izmir, University of Perpignan Via Domitia (France), Muğla Sıtkı Koçman University, and Al-Faisal University - Jeddah (Saudi Arabia). Research interests focus on; cultural tourism, heritage interpretation and management, tourism marketing, business etiquette, francophonie, tour guiding, MICE, GCC and MENA regions, and ecotourism. 